\title{
FASHION, MEDIA AND GENDER IN CHRISTIAN SCHAD'S PORTRAITURE OF THE 1920s änne söll
}

In her book Seeing through Clothes, Anne Hollander develops the idea that fashion only exists through visual media. For Hollander, fashion and media cannot be separated. We dress with images of fashion in mind: 'It is an essential fact that without the constant reference of its interpretation, fashion could not be perceived. Certain ways of looking could not be seen as more desirable than others, as acceptable or in need of subversion or further exaggeration, without the visual demonstration that pictures provide' (Hollander 1993: 350). Hollander extends her argument further to claim that clothes are designed and worn in order to work well in certain media and that the right kind of medium can 'elevate the current fashion to the level it aspired to' (Hollander 1993: 331). Thus, it comes as no surprise that, for Hollander, the shift to a creative kind of fashion photography in the 1920 s is accompanied by a change in women's clothes which, together with photography and eventually film, produced a look that reflects spontaneity, simplicity and movement. 'Clothes,' claims Hollander, 'are designed for the flashbulb' (Hollander 1993: 329). Painting, she concludes, is at a loss: 'Ever since photography acquired its total graphic authority, it is the painted portraits of people in modern elegant clothing that have become frumpy-looking' (Hollander 1993: 328). Taking Hollander's claims as its point of departure, this chapter will deal with a pair of what Hollander calls 'frumpy-looking' portrait paintings produced at the moment 
when photography began to be the principal medium for the representation of fashion. The portraits in question, entitled Count St. Genois d'Anneaucourt (dated 1927) (Plate 21) and Baroness Vera Wassilko (dated 1926) (Plate 22), were painted by the German painter and photographer Christian Schad in the style of New Objectivity (Neue Sachlichkeit). In contrast to all of Schad's other portraits, the sitters for these pieces have never been clearly identified, despite the apparent exactness of information regarding their names provided in the titles. Though painted a year apart, Schad conceived the portraits as belonging together, and they should be seen as a couple. ${ }^{1}$ Their repeated use as book covers and illustrations in art historical literature on the 1920s has made the pair emblematic of a decade characterized by social and economic upheaval, a decade dominated by a shift in gender relations and radical change in women's fashion, as well as a proliferation of mass entertainment and fashionable nightlife. I will argue here, in opposition to Hollander's view, that these portraits are far from 'frumpy'; that in his treatment of fashion and paint in relation to the gendered body, Schad manages to bring to portrait painting both fashionability and chic in a single stroke. Indeed, as I will argue, it is the very challenge of photography itself that makes these portrait paintings endure and attractive still today. Rather than photography superseding painting, if you will, it is, in fact, the productive tension between the two media, painting and photography, that gives rise to a visual space in-between, a space that allows for the gendered body to become visible and negotiable through the embodiment of fashion in paint.

\section{FASHION, PHOTOGRAPHY, PAINTING}

With few exceptions, German fashion magazines around the time of the First World War employed studio photographs in the tradition of nineteenth-century portrait photography, which, in the spirit of painted portraiture, showed women in artificial settings in a series of theatrical poses (Figure 7.1) owing much to the dramatized photographic portraits of nineteenth-century actresses (Holschbach 2004: 205-15). Photography was considered an indexical medium that provided the viewer a glimpse of 'reality'. It was mainly fashion illustrations, then, which expressed artistic, individual perspectives on fashion, incorporating references to new ideas on lifestyle, alluding to a narrative and/or referencing a particular avant-garde style, such as expressionism or art deco (Dogramaci 2006). Influenced by what in Germany was called Neues Sehen (New Vision), photography became a major player in German fashion media by the 1930s, on equal footing with-if not surpassing — fashion illustration. Laszlo Moholy-Nagy's 1927 book Malerei, Fotografie, Film illustrates what the new aesthetics meant for photography: extreme viewpoints, spontaneity, graphically designed images working with strong light and shadow contrasts. Through these techniques, photography was to become a means of artistic self-expression, experimentation and unique style. But for photography to be able to rise to the status of artistic medium, it had to emancipate itself from painting, still considered the superior and most noble medium of art and the one best suited for portraiture. The materiality of paint and its application by the painter was thought to better lend itself to artistic thought than the photographic lens. Light and paper were considered too immaterial to be able to convey what painting could show through the material and physical treatment of paint and canvas. Ernst Kallai's essay 'Painting and Photography', published in 1927 in the Dutch avant-garde magazine $i-10$, opened up a debate that would define the future of photography. Here, Kallai argued that photography lacks what in German is called Faktur, or 


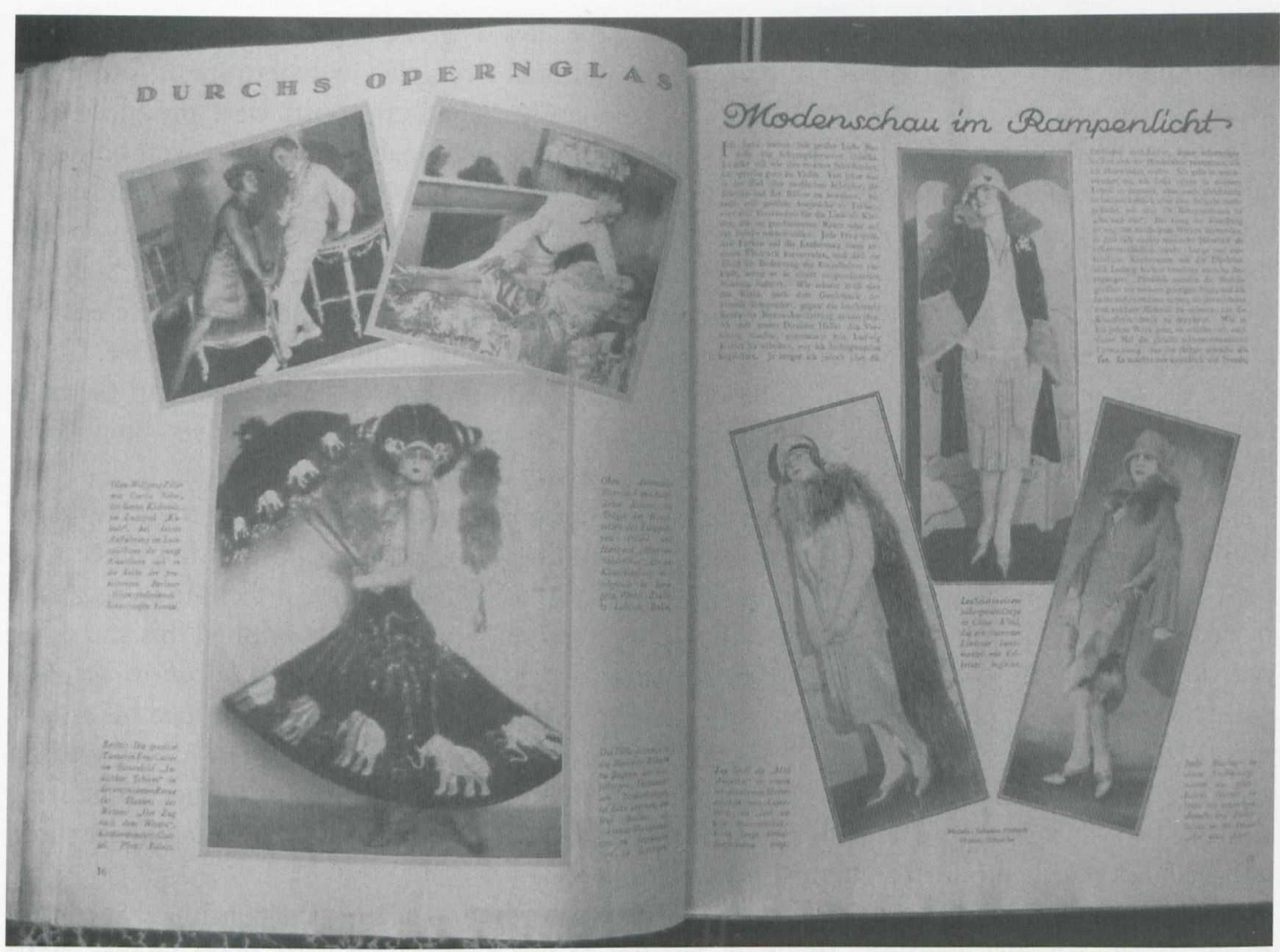

7.I. Elegante Welt, September 1926

the visible signs of the artist's application of paint on canvas. Without the physical trace of the artist, photography, in Kallai's mind, was neither able to express the mental state of the artist nor to reflect its own creative process through the treatment of its material. Moholy-Nagy, however, argued that light was, in fact, an artistic 'material' that produced something he called 'Licht-Faktur', which enables artistic expression in photography as paint does in painting. For Kallai's opponents in the debate, the camera was not merely a technical instrument only able to document reality but the equivalent of the painter's brush and, therefore, a valid means of personal and artistic expression (Kallai 1927). ${ }^{2}$ It is through the work of Moholy-Nagy and others that photography emancipated itself from the constraints of its putative indexicality -its status as a tool for recording what is - and began to be seen as a creative medium which would eventually dominate the public domain through its increased use in magazines and newspapers. ${ }^{3}$

In the aftermath of these debates of the 1920s and 1930s, the depiction of fashion in Germany became marked by an ongoing tension between painting and photography. In 1926 and 1927, when Christian Schad produced his couple in question, German fashion photography continued to be dominated by a type of theatrical studio photography in the spirit of Adolph de Meyer and the glamorous fashion portraits of Edward Steichen. Tobia Bezzola astutely discerns the latter's work as inspired and invigorated by and essentially rooted in the tradition of painted portraiture. He writes, 'Steichen's photographs for Condé Nast-as stylistically and methodologically diverse as 
they are - are united in their drive towards elevating the "lower" genre of portrait photography and fashion photography with the help of painting's traditional strengths, its repertoire of forms and ideas' (Bezzola 2008: 194, my translation). Consequently, Schad's portraits were produced at a time when the boundaries between fashion photography and fashionable portraiture were being renegotiated. Painting and photography were not merely in competition with one another but rather became participants in a close and productive dialogue. For this discourse, Schad's portraits constitute a prime example because they relate both to fashion photography in the manner of Steichen and to realist painted portraiture. By painting in the New Objectivity style, he makes reference to photography's indexical qualities at the same time he shows us painting's power to deceive. Compared to the relatively stiff and old-fashioned-looking fashion photographs available in German fashion magazines of the mid-1920s, Schad's portraits are cool, subtle and seductive - in a word, modern - using fashion to lure us into an unstable but attractive visual constellation.

Christian Schad always considered himself a painter; he experimented with photography as an artistic medium and created Schadographs, cameraless images created by positioning objects on light-sensitive paper, producing uncanny, abstract black-and-white shapes, a technique also used by Man Ray and Moholy-Nagy. By the early 1920s, however, Schad had abandoned this and other practices inspired by Dada and surrealism for what is now known as Neue Sachlichkeit. Yet, as a painter, Schad's dialogue with and interest in photography did not end when he stopped his experiments in photography in the early 1920s. Painting and photography converge in his oeuvre and are taken up self-consciously, informing one another and played off against each other at the same time: in his paintings in the style of New Objectivity, he uses painting as if he were taking pictures, and he takes photographs in an almost painterly manner.

On the whole, New Objectivity is best described as a reaction against the continued predominance of expressionist painting. The main features of this new realism were sharp images, static compositions and sober engagement with technology and daily life, producing paintings with a smooth, almost shiny surface. Though most artists working in the new mode were well aware of photography as an artistic medium, ${ }^{4} \mathrm{New}$ Objectivity painting did not necessarily resort to photography to redevelop this new kind of realism. Instead, these paintings relate to a tradition in nineteenth-century realism, the contemporary Italian style of Pittura Metafisica as much as certain types of Renaissance painting, especially in portraiture. Schad's travels in Italy allowed him to study Renaissance portraiture first-hand, and it is a well-documented fact that Schad used paintings such as Raffeal's La Fornarina as inspiration for his own images (Mirabile 1997). But Schad never stopped photographing. In fact, he used his own portrait photographs and pictures of Paris to help create his painted portraits (Lloyd 2003). Considering both Schad's experimental, almost painterly Schadographs and his photographic portrait paintings, it is evident that both techniques inform each other in his work.

Though photography would eventually become the primary medium for representing fashion, it was painting in the form of fashionable portraits that was featured on most covers of German fashion magazines in the 1920s and 1930s. Schads portraits of fashionable ladies and starlets were also used as covers for magazines such as Die Dame, Jugend and Sport im Bild, as the portrait of the actress Mulino von Gluck from 1930 shows (Plate 23). The employment of portrait paintings as covers is indicative of painting's status as the superior artistic medium. Yet, portrait painting was never considered a medium for fashion but rather the inverse. The portrayal of fashion was thought to be a by-product of portrait painting, since its main aim was to convey the personality and soul 
of the sitter, not the extravagance or banality of his or her attire. While dress, as Aileen Ribeiro (1999) has made the case for Ingres's portraits, has become an art form in its own right within the genre of traditional portraiture, generally, depictions of clothing and fashion were always considered subordinate to the latter's pre-eminent aims. Nevertheless, clothing and/or fashion in portraiture can develop a life of its own - as the German art historian Wolfgang Waetzold pointed out as early as 1908, writing, 'Independently from the sitter, clothing can develop in its very own interest, a material and structural quality, thereby showing the charms of its surface' (Waetzold 1908: 197). The hierarchy of the arts, separating high from low, or dividing applied arts from fine arts, ensured that in 1926, fashion was still seen to be in the service of portraiture. In his 1926 catalogue essay for one of the very first fashion exhibits in Berlin to combine portraiture and fashionable clothes, the curator Wolfgang Bruhn writes, 'The images of women by classicist painters, by the romantic school, the dynamic painters of representative women's portraiture of the 1850 s and $1890 \mathrm{~s} \ldots$ all know how to put colour, decoration and the tactile quality of surfaces in the service of portraiture without losing psychological depth' (Bruhn 1926: 4, my translation). So, to Bruhn, the depiction of fashionable clothes puts portraiture in danger of being superficial. Thus, for portraiture not to become a fashion in itself, it had to keep fashion in check. Portraiture, on the other hand, could lend to fashion what fashion did not seem to possess itself-namely, the status of art. In his paintings, Schad works with the tensions between the allure of fashion's surfaces and the noble aims of portraiture. By citing and then reinterpreting the staid-looking German fashion photography of the time with the means of realist painting, he is able to use fashion's potential to play with surface, appearance and depth to disturb ideas of gendered identity.

\section{SEE-THROUGH DRESSES, TRANSPARENT GENDER?}

Not being particularly popular at the time of their production, Schad's portraits have only become well-known since the 1960s, when a new wave of interest in New Objectivity began. Schad's selfportrait from 1927, in particular, is one of the most reproduced images of New Objectivity portraiture, owing its notoriety mainly to Schad's see-through outfit, which veils the torso as much as it exposes it (Plate 24). ${ }^{5}$ The presentation of bodies in transparent clothes is a feature Schad also employs in the portraits the count and the baroness (Plates 21 and 22). The main contrast in both paintings stems from the difference created by the flimsy, see-through material of women's dresses and the dark opaque surface of men's evening clothing. Though transparent material is more commonly associated with 1920 s women's fashion, we also see a male body adorned with translucent fabric in the portrait of the count. The transvestite to the count's right wears a rose-coloured sheath dress that reveals his naked buttocks. The dress leaves much of his back exposed, directing our gaze to a black spot near his upper right shoulder, which might be a mole, a beauty spot or perhaps even a sign of venereal disease. ${ }^{6}$ The woman on the count's left and, in the companion piece, the Baroness Vera Wassilko herself, are also wearing transparent dresses, revealing the female bodies beneath. This voyeuristic effect is counterbalanced in the first instance by the diverted gaze of the woman toward the upper-right-hand corner, while the baroness's blank stare appears immune to the viewer's gaze, looking through and beyond its potentially objectifying effect. The bunch of violets, which hold the baroness's dress together, served in the 1920s as a symbol of lesbianism (Schader 2004: $170-5)$. This suggestion of the baroness's sexual orientation towards other women together with 
the count's association with the figure of the male transvestite undercut the assertion made by the portraits of the count and baroness as a noble, heterosexual couple. This ambiguity concerning their sexual orientation is likely the reason why the existence of count and baroness could never finally be verified: because of their sexual orientation, they probably were and had to be a product of fiction, and the realist style of New Objectivity helped to make this deception even more effective. Clearly, then, a photographic portrait was never an option.

Whereas the count and baroness themselves show no obvious signs of their sexual orientation, their bystanders do. Especially the body of the transvestite to the count's right is revealed as deviant. Like Schad's own body in his self-portrait, it is exposed as a painted surface, presented as an image to be looked at. The transvestite's dress fits so tightly that the ornamental flowers on the upper part of the garment look as if they are tattooed or painted directly onto his body, collapsing the distance between skin and dress, painted surface and corporeal surface. It is this effect, not the woman's dress alone, that makes the transvestite's body look especially effeminate and brings it in line with the objectification of women's bodies as a 'passive' image, making the (female) body available to the (male) viewer. The effect is underscored by his make-up, which in comparison to the face of the woman on the left, and through difference in colour and brush strokes, is clearly shown as 'painted' on, so that the process of painting is foregrounded as an element of the transvestite's artificialness and gender ambiguity. Moreover, the material quality of the transvestite's transparent dress functions as a double surface that veils and exposes the surface of the painting and the surface of the male body at the same time-an effect that is especially visible in the lower half of the transvestite's body. Instead of presenting the male body as an impenetrable, black surface negating itself, Schad playfully reveals the male body through a layer of translucent paint. The materiality of painting, then, referenced by the transvestite's mask-like make-up-in conjunction with the materiality of the dress as a surface which at once both covers and reveals-is shown to be responsible for the artificial process of making-up and part of the performance of gender displayed here. In the same way the figures in the painting are not always what they appear to be, the 'realism' of the painting is exposed as artificial.

Whereas the women's clothing in these images lets the body shine through, men's dress is characterized by a variety of black evening outfits that mask the body almost completely. This does not mean that the bodies underneath these suits are de-eroticized, however. The male suit is not only part of the 'Great Renunciation' (Flügel 1930) in male clothing since the mid-nineteenth century, it is also a sign of phallic power. What is more, it evokes, as Anne Hollander has shown, an idealized, classical male body that combines male beauty, authority and sex appeal. But, just as the women's dresses do not guarantee a female body underneath or, as in the case of the baroness, women's dress does not necessarily indicate female heterosexuality, the men's tuxedos are equally unstable signs for male bodies and male heterosexuality.

In the count's portrait, this ambiguity is achieved by positioning him between the woman on the left and the transvestite on the right, suggesting his undefined sexual orientation. In the baroness's portrait, ambiguity is introduced by cutting off the heads of the men on either side of her, turning them into fragments. The body fragment of the figure to her right is also supplied with a manicured, female hand which destabilizes the gendered meaning of the tuxedo. Just as the transvestite is in drag, so could the 'man' on the baroness's right be female. Through his ambiguous treatment of the vestimentary signs of sexual orientation and gender, Schad suggests the potential homosexuality of the sitters, hitting the nerve of the contemporary discourse on transvestism, 
homosexuality and sexual identity. At the time of the painting's production in the mid-1920s, the discussion on sexual identity and gender in Germany was fuelled by the research of Berlin-based sexologist Magnus Hirschfeld, whose findings on transvestism showed that it was not a sure sign of homosexuality but could also be practiced by heterosexuals or bisexuals (Hirschfeld 1920: 236). In the 1920s, even within the homosexual scene, transvestites occupied ambiguous terrain. As Mel Gordon explains, 'Male transvestites projected a weak, jaded, and mocking reflection of same-sex male desire; a dangerous and irreparably haunting challenge to phallocentric gays and their Hellenistic theories of male supremacy and soldierly rectitude of man-boy love. Men in drag were regarded as Untermänner' (Gordon 2006: 120). By dressing the transvestite in women's fashionable evening clothes, which, unlike practical everyday wear for women, emphasized traditional femininity through the generous use of soft, shiny or see-through and flowing material, Schad makes the transvestite look like a parody of femaleness, ridiculing femininity as much as the attempt to look like a woman. 'Real' men, homosexual or heterosexual, could never be seen wearing translucent clothes, as this piece of advice from a men's magazine makes clear: 'A beautiful man impresses through his manly appearance, and if he has taste he circumvents everything, which emphasizes his body in a crude way. A transparent women's stocking can be charming. A transparent men's sock is ridiculous and therefore not elegant. Absolutely no female finesse! It discredits all masculinity' ('Editorial' 1917: 19, my translation). ${ }^{7}$ Under no circumstances was the average man's skin to be put on public display and eroticized. Men's bodies were hinted at through the structured surface of the suit that offered a neutral surface. Nothing illustrates these rules better than the juxtaposition of the black-clothed, almost nonexistent body of the count and the rose-coloured body of the transvestite exposed by the flimsy, see-through material. Thus, women dressing up as men could play with or even aspire to the authority associated with men's clothing. Aspiring to or playing with femininity and femaleness, as we see in the rejection of transvestites by phallocentric gay male culture, is not something men should do (Gordon 2006: 120). Men dressing up as women caused unspeakable anxiety over sexual difference and loss of power, that, in contrast to women's masculine dress, 'could not be relieved through any promise of liberation, equality, and casual dressing' (Hake 1997: 188).

As has been proven by a wide variety of research on women's dress in the 1920s, fashion served a key function in the visual process of women's liberation and questions of gender and sexual identities (Hake 1997; Bard 1998; Kessemeier 2000; Follmann 2010). As Sabine Hake points out, 'Many descriptions of the so-called New Woman revolve around fashion... Fashion played an important role in defining modern femininity: as a marker of economic status and social ambition, as an expression of female narcissism and beauty, and as a focus of consumerist fantasies and commodified versions of the self' (Hake 1997: 185). With prewar Reformkleidung (reform dress) having paved the way for fashion to signal women's recently acquired literal and figural freedom of movement and the new introduction of ready-to-wear clothing, which made fashion available to a larger section of society, fashion 'came to be associated with a variety of causes, from the fight for sexual freedom and women's rights to the conservative campaigns against rampant consumerism and the Americanization of Germany' (Hake 1997: 185). In the years 1925 through 1929, when Germany enjoyed relative economic stability and Schad's portraits were painted, it was women's fashion that ignited debates about the problems of modernity and 'articulate[d] its contradictions in gendered terms' (Hake 1997: 185). Especially during the mid and late 1920s, women's fashion 'promised sexual liberation, social mobility and narcissistic gratification outside the confinements 
of traditional identity politics' (Hake 1997: 186). The most hotly debated look was the garçonne style, where elements of men's sporting, work and evening dress were adopted by women's fashion, producing a 'flirtation with masculinity' which 'involved a playful staging of identities that was predicated on the full achievement of gender equality, and given the imaginary nature of such assumptions, often highly ironical and self-reflexive' (Hake 1997: 196). Whereas this masculine look for women could already be adopted by certain movie stars such as Marlene Dietrich and other celebrities, causing scandals and much-wanted publicity, men dressing up as women in public remained unthinkable: 'Manliness was all the rage. The men of the twenties searched themselves for vestiges of effeminacy as though for lice' (Crisp 1983: 21). Men's cross-dressing was not part of the public fashionable world but was strictly confined to certain nightclubs, where it could clearly be seen as staged and therefore kept at bay. Schad sets the scene of the count's portrait in such a club when he comments that he had seen the transvestite in the Berlin nightclub Eldorado (Schad 1997). In the Eldorado, fashionable (mostly heterosexual) Berliners and international tourists were presented with equally fashionable transvestites. At the time, the Eldorado was described by a popular guide book about 'sinful' Berlin as a place where 'transvestites have been put on display for national and international tourists... A grande dance hall for an elegant audience. Smoking, evening cut and grande evening dresses- this is how the average person presents him and herself, the guests have come here to stare' (Moreck 1931: 180, my translation). This reveals that the Eldorado was not a club for transvestites, but a club mostly for heterosexuals to look at transvestites. ${ }^{8}$ Without necessarily having to question one's own sexual orientation or even gender, the visitor to the Eldorado could experience a space where the world of sex and gender was turned upside down, a space where clothing did not signal one's sexual orientation or gender. The visitor enjoyed this spectacle of exotic deviance, like going to the zoo. Again, the guide book provides a good description of the Eldorado's atmosphere: 'This is right, one can read on the advertisements. An ominous slogan, which gets the imagination going. The place is a stage, only the absolute naive believe the transvestite's authenticity. Even the real transvestites, who make money with their sexual deviance, turn into actors here' (Moreck 1931: 180-1, my translation). And so could the visitors. In play with the real or fake transvestites, the visitors' dress loses its power to denote 'real' gender and sexual orientation, as well. In his portrait of the count, Schad leaves it up to the viewer to decide which stance to assume, whether to take the attitude of the distanced audience described above or to reflect on the gendering effect on one's own clothes. Thus, Schad's presentation of transvestism not only thematizes homosexuality but also raises the issue of heterosexuality as a construct. By making the baroness and count a 'couple', as well as showing each of them in a threesome of unclear sexual orientation, the dichotomy of male/female (husband/ wife) is thrown into crisis, a crisis that has been described by Marjorie Garber as transvestism's key function. She writes, 'Transvestism is a space of possibility, structuring and confounding culture: [crisis is] the disruptive element that intervenes, not just a category crisis of male and female, but the crisis of category itself' (1997: 17).

To this crisis of gender and sexual identity can be added one of portrait painting, which was being challenged by photography as prime medium for portraiture and artistic expression in general. This crisis was seen to be connected to a destruction of male, bourgeois individuality through the effects of modernity. The rise of photography was considered to mirror this threat, producing nameless faces of types rather than individual beings (Meyer-Büser 1994: 85-9). 


\section{CONCLUSION}

The 1920s were a time when the individual, gendered self-image was felt to be in flux, if not altogether in danger. Schad's portraits of the count and baroness address these fears on the level of gender identities in a medium that was equally under duress, using the tensions between painting and photography to make the crisis of gender identity visible. In this, fashion functions as an intelligent membrane that registers these tensions and provides the tenuous, transparent surfaces that negotiate between or collapse the body of the sitter and the materiality of paint, creating an ambiguous and productive illusion of appearances. In the dawning age of modernist fashion photography, Schad produced realist portrait paintings to convey the ambiguous potential of fashion and its relationship to gendered identity. Schad dealt with his media very much on a conscious level, pushing them to their limits: he used his knowledge of photography not to produce realist images but emphasized photography's painterly and tactile quality and photography's potential for abstraction. At the same time, Schad revives portrait painting and brings to the fore its ability to produce colourful, sensuous, multilayered, see-through or opaque surfaces, which seem to be hyperreal. Literally, the gendered, dressed body is seen to be a surface phenomenon. By looking at Schad's Count and Baroness, 'seeing through clothes' doesn't mean you see the truth or the core; instead you see just another surface open for interpretation.

\section{ACKNOWLEDGEMENTS}

For translation and comments, I thank Staci von Boeckmann and Shaun Cole.

\section{NOTES}

1. See Schad's commentary in Bezzola 1997: 104.

2. Kallai's thesis was discussed by Willi Baumeister, Wassily Kandinsky, Laszlo Moholy-Nagy and others.

3. By the 1930s, the photographic style of Neues Sehen made its way into fashion magazines as part of general reporting on lifestyle issues, travel and so on. It is only in the early 1940 s that it is generally used in fashion photography. Because so many photographers who were working in the style of Neues Sehen (such as Martin Munkasci) were forced to emigrate to the United States in the 1930s, fashion photography in the style of Neues Sehen spread much more quickly in US fashion magazines such as Vogue or Harper's Bazaar.

4. Most artists who practiced this new realist painting were well aware of new developments in photography and used photographs for their work. Some of them were amateur photographers themselves. For a general overview of the connection of New Objectivity painting and photography in Germany, see Michalski 1992: 180-202.

5. For a detailed analysis of Schad's self-portrait, see Söll 2006.

6. This section of Schad's painting was used as cover illustration for the New York's Metropolitan Museum's catalogue of its show on German portrait painting of the 1920s in 2009 called Glitter and Doom. By focusing on the transvestite's face and dark spot, his potentially sick and sexually ambiguous body becomes the sign for Weimar Germany's demise.

7. Although this comment stems from 1917, it is equally valid ten years later at the time of the portrait's production. 
8. In 1920s Berlin, transvestites had their own clubs, strictly divided into venues for homosexual or heterosexual transvestites. Since there were serious disputes between heterosexual and homosexual transvestites, they would not frequent the same bar; on this issue, see Herrn 2005: 142-3.

\section{BIBLIOGRAPHY}

Bard, C. (1998), Les Garconne. Modes et fantasmes des Années folles, Paris: Flammarion.

Bezzola, T., ed. (1997), Christian Schad. 1894-1982, Zürich: Wienand.

Bezzola, T. (2008), 'Lights Going All Over the Place', in W. Ewing and T. Brandow (eds), Edward Steichen. In High Fashion, Seine Jahre bei Conde Nast 1923-1937, Ostfildern: Hatje Cantz: 187-97.

Bruhn, W. (1926), Das Frauenkleid in Mode und Malerei vom 18. Jahrhundert bis zur Gegenwart, Berlin: Staatliche Kunstbibliothek.

Crisp, Q. (1983), The Naked Civil Servant, New York: Plume.

Dogramaci, B. (2006), 'Die Modefotografie der Weimarer Republik im Spannungsfeld zwischen Modegrafik und Fotoreportage', in U. Rütter (ed.), Think while You Shoot. Martin Munkasci und der moderne Bildjournalismus, Hamburg: Conference Point Verlag, 43-58.

'Editorial' (1917), Die Herrenwelt, February: 2.

Flügel, J. C. (1930), The Psychology of Clothes, New York: International Universities Press.

Follmann, S. (2010), Wenn Frauen sich entblößen... Mode als Ausdrucksmittel der 1920er Jahre, Marburg: Jonas Verlag.

Garber, M. (1997), Vested Interests. Cross-dressing and Cultural Anxiety, London: Routledge.

Gordon, M. (2006), Voluptuous Panic. The Erotic World of Weimar Berlin, Los Angeles: Feralhouse.

Hake, S. (1997), 'In the Mirror of Fashion', in K. von Ankum (ed.), Women in the Metropolis. Gender and Modernity in Weimar Culture, Berkeley: University of California Press, 185-202.

Herrn, R. (2005), Schnittmuster des Geschlechts. Transvestiten und Transsexualität in der frühen Sexualwissenschaft, Giessen: Psychosozial-Verlag.

Hirschfeld, M. (1920), Die Homosexualität des Mannes und des Weibes, 2nd ed., vol. 3, Berlin: Marcus.

Hollander, A. (1993), Seeing through Clothes, Berkeley: University of California Press.

Holschbach, S. (2004), 'Fotografische Rollenporträts und medialer Transfer-Schauspielerinnen im Atelier des 19. Jahrhunderts', in S. von Falkenhausen (ed.), Medien der Kunst, Geschlecht, Metapher, Code, Marburg: Jonas Verlag, 205-15.

Kallai, E. (1927), 'Malerei und Fotografie', i-10, 4: 148-57.

Kessemeier, S. (2000), Sportlich, Sachlich, Männlich. Das Bild der Neuen Frau in den Zwanziger Jahren, Dortmund: Ebersbach.

Lloyd, J. (2003), 'Christian Schad. Reality and Illusion', in J. Lloyd and M. Peppiatt (eds), Christian Schad and the Neue Sachlichkeit, New York: Schirmer Mosel, 15-28.

Meyer-Büser, S. (1994), Das schönste deutsche Frauenportrait. Tendenzen der Bildnismalerei in der Weimarer Republik, Berlin: Reimer.

Michalski, S. (1992), Neue Sachlichkeit. Malerei, Graphik und Photographie in Deutschland 1919-1933, Cologne: Taschen.

Mirabile, B. (1997), 'Schad und Italien', in T. Bezzola (ed.), Christian Schad. 1894-1982, Zürich: Wienand, 155-64.

Moholy-Nagy, L. (1927), Malerei, Fotografie, Film, Munich: Langen.

Moreck, C. (1931), Führer durch das lasterhafte Berlin, Leipzig: Verlag moderner Stadtführer.

Ribeiro, A. (1999), Ingres in Fashion: Representations of Dress and Appearances in Ingres's Images of Women, New Haven, CT: Yale University Press.

Schad. C. (1997), 'Commentary to the Portrait of Count St. Genois d'Anneaucourt', in T. Bezzola (ed.), Christian Schad. 1894-1982, Zürich: Wienand, 118. 
Schader, H. (2004), Virile Vamps und wilde Veilchen. Sexualität, und Begehren und Erotik in den Zeitschriften homosexueller Frauen im Berlin der 1920er Jahre, Königstein: Helmer Verlag.

Söll, Ä (2006), 'Stoffe, Narben, Nähten. Geschlechterdiskurse in Christian Schads Selbstbildnis von 1927', in S. Scholz und G. Engel (eds), Kopf-und andere Tücher, Berlin: Trafo Verlag, 103-16.

Waetzold, W. (1908), Die Kunst des Porträts, Leipzig: Hirt. 